\title{
Treść nazwy ,konfiskata” $w$ świetle niektórych wypowiedzi literatury na temat reorganizacji domeny monarszej przez Kazimierza Wielkiego
}

\section{Bedeutung des Begriffs ,Konfiskation” aus wissenschaftlicher Sicht über die Reorganisation der königlichen Domäne, die von Kasimir dem Großen durchgeführt wurde}

1. Dwie sytuacje, w jakich Kazimierz Wielki zabierał dobra nieruchome bẹdące własnością poddanych: konfiskata i zabór. 2. Wieloznaczność słowa „konfiskata” w polskim jẹzyku potocznym i próba jego uściślenia w języku nauki. 3. Znaczenia nadawane nazwie „konfiskata” w literaturze. 4. Wyniki.

1. Zwei Situationen, in denen Kasimir der Groe die den Untertanen gehörigen Erdengūter beschlagnahmt: Konfiskation und Wegnahme. 2. Mehrdeutigkeit des Wortes „Konfiskation” in der polnischen Umgangssprache und Versuch einer Präzisierung in der Fachsprache. 3. Bedeutung des Begrifls „Konfiskation” in der Literatur. 4. Resultate.

Wśród kar stosowanych $w$ średniowieczu wyróżnia się tzw. kary rzeczowe czy też majątkowe. Spośród nich na pierwsze miejsce wysuwa sie konfiskata. Józef Matuszewski, Pisma wybrane, t. II, s. 5.

Wiadomo, że Kazimierz Wielki - podobnie jak inni panujący w średniowiecznej Polsce - zabierał cudze majątki w dwu sytuacjach: kiedy stosował karę konfiskaty (przepadku) mienia (sytuacja 1.$)^{1}$ bądź bez związku z popełnieniem przestępstwa przez ich właściciela, wówczas gdy dobra należące do

\footnotetext{
${ }^{1}$ W literaturze nazwy „konfiskata” i "przepadek mienia” bywają czasem używane zamiennie na oznaczenie tej samej instytucji prawa karnego. Zob. J. Luciński, Majatki ziemskie panującego w Malopolsce do 1385 roku, Poznań 1967, s. 11 i 16. Współczesnemu polskiemu prawu karnemu kara konfiskaty nie jest znana, lecz przepadek, który chociaż z konfiskatą genetycznie powiązany, stanowi odmienną instytucję. Zob. K. Postu1ski, M. Siwek, Przepadek w polskim prawie karnym, Zakamycze 2004, s. 19 i n.
} 
poddanych $\mathrm{z}$ jakichś względów okazywały się dlań potrzebne ${ }^{2}$, lub jeśli potraktował je niesłusznie jako podlegającą rewindykacji własność monarszą (sytuacja 2.) ${ }^{3}$. W obu przypadkach właściciele tracili majętności wbrew swej woli i nie otrzymywali też za nie ekwiwalentu.

W opinii posiadaczy ziemskich król Kazimierz działal prawnie wtedy, kiedy zabieral majątki w sytuacji 1 ., oraz gdy odbieral własne posiadłości ${ }^{5}$. Inne wypadki zabierania dóbr (sytuacja 2.) byly oceniane jako dokonane minus iuste ${ }^{6}$. Stały się przeto źródłem konfliktu społeczności ziemian z monarchią, który z całą siłą ujawnił się po śmierci Kazimierza. O pozbawieniu kogoś majątku decydowała $w$ takich razach arbitralna wola panującego. Natomiast kara konfiskaty orzekana bywala, choć nie zawsze, na drodze sądowej ${ }^{7}$. Jeśli przestępca lub jego rodzina podejmowali starania o restytucje zabranego majątku, musieli liczyć na laskę monarchy; ci zaś, którym król zabral dobra $\mathrm{z}$ innego powodu, a więc minus iuste, opierali swoje pretensje na prawie własności ${ }^{8}$. Nie jest przeto kwestią bez znaczenia, $\mathrm{z}$ jaką sytuacją spotykamy się w źródłach, gdy informują one, iż król Kazimierz zabral komuś posiadłość. Wprawdzie obie powodowały - jak wspomniano - prze-

${ }^{2}$ Inne, niż ukaranie przestępcy, przyczyny zabierania majątków szerzej przedstawia J. Lu c iń ski, Majątki..., s. 26-28.

${ }^{3}$ Podjęta przez króla na dużą skalę rewindykacja posiadłości należących do domeny monarszej stanowiła prawdopodobnie dogodny pretekst dla urzędników królewskich do zabierania również cudzych majętności, możliwe też były pomyłki i falszywe doniesienia o tym, iż dana nieruchomość stanowi własność monarszą, wreszcie sami posiadacze być może nie zawsze potrafili dowieść tytułu prawego dzierżenia dóbr. Oprócz tego król Kazimierz dokonywał rzeczywiście rewindykacji zagarniętych posiadłości monarszych, a nie zaboru cudzych dóbr.

${ }^{4}$ Poruszony tu $\mathrm{w}$ skrócie problem zabierania cudzych posiadłości przez panującego $\mathrm{w}$ średniowiecznej Polsce stanowi przedmiot odrebnej pracy, przygotowywanej obecnie do druku.

${ }^{5} \mathrm{Za}$ uznawaniem prawa panującego do windykacji własnych dóbr przemawia na przykład dokument z 1348 r. (KDWP 2, nr 1275), w którym Kazimierz Wielki zwraca arcybiskupowi gnieźnieńskiemu Bąków wraz z kilkoma innymi wsiami. Król adebral je jako swoją własność, działając w dobrej wierze na podstawie fałszywej, jak się później okazało, informacji: ...quia ex mala et sinistra suggestione informati, quod ville infrascripte [...] ad nos pertinerent, intromiseramus nos de ipsis. Wynika stąd, iż gdyby owe wsie były rzeczywiście własnością monarszą, to król Kazimierz miałby prawo je odebrać. Usprawiedliwienie króla dokonującego zaboru, o jle miało spełnić swój cel, musiało - jak sądzimy - odwoływać się do poglądów rzeczywiście podzielanych przez społeczność posiadaczy ziemskich. Ta okoliczność nie przesądza jednak o tym, czy faktycznie król co do Bąkowa został wprowadzony w błąd. W tej kwestii powołana wzmianka jest być może tylko czczym frazesem, bowiem w roku poprzedzającym restytucję Kazimierz zatwierdził uposażenie arcybiskupstwa, a w tym również Bąkowa oraz pozostatych wsi (KDWP 2, nr 1354, s. 70).

${ }^{6} \mathrm{~K}$. Goźdź-R os zkowski, Zabieranie cudzych dóbr ziemskich przez panujqcego $w$ ocenie prawnej sq̨dów królewskich dzialajqcych $w$ Wielkopolsce $w 1372$ r., [w:] Studia $z$ dziejów panstwa $i$ prawa polskiego, t. VIII, Lódż 2003, s. 102 i n.

7 J. Matus zewski, Problem konfiskaty dóbr szlacheckich $w$ dawnej Polsce, [w:] te n że, Pisma wybrane, t. II, Lódź 2000, s. 6.

${ }^{8}$ K. Goźdź-R oszkowski, Zabieranie..., s. 96. 
sunięcie majątku nieruchomego $\mathrm{z}$ rąk prywatnych do królewskich, wbrew woli właścicieli i bez ekwiwalentu, to jednak różnią się one w znaczącym stopniu pod względem prawnym ${ }^{9}$. Wszakże wlaśnie prawna strona problemu zabierania cudzych majątków przez króla, z powodów innych niż popełnienie przestępstwa (sytuacja 2.), nasuwa szereg trudności badawczych pojawiających się między innymi wówczas, gdy przychodzi zdecydować, czy poznany wypadek zabrania dóbr odpowiada wspomnianej drugiej sytuacji, czy też jest rewindykacją. Przyczyna trudności tkwi nie tylko w źródłach, które $w$ istotnych kwestiach bywają lakoniczne bądź milczące ${ }^{10}$, lecz także $w$ tym, iż szereg zagadnień dotyczących prawa własności dóbr ziemskich jeszcze wciąż pozostaje niedostatecznie zbadanych ${ }^{11}$.

Dla wskazanych wyżej dwu sytuacji, w których dochodziło do zabierania poddanym ich wlasności nieruchomej, polski język potoczny ma jedną nazwę - „konfiskata" ${ }^{\prime 2}$. W literaturze próbowano rezerwować ją dla sytuacji pierwszej ${ }^{13}$, tam natomiast, gdzie zachodzil wypadek zabrania cudzych dóbr bez związku z popełnieniem przestępstwa, proponowano nazwę

9 Roźóżnienia między karą konfiskaty a zabieraniem cudzych dóbr przez panującego $\mathrm{z}$ innych powodów niż przestępstwo właściciela dokonał po raz pierwszy K. Potka ński, Sprawa restytucji (Rok 1374 i 1381), Kraków 1900, odb. z t. XXXIX Rozpraw Wydz. Hist.-Filoz. AU w Krakowie, s. 16-17, przedruk. w: K. Potk án ski, Lechici, Polanie, Polska. Wybór pism, Warszawa 1965, s. 591-594. (cyt. wyd. z 1900 r.).

${ }^{10}$ Wzmianki o zabieraniu dóbr przez panujacego w dokumentach z XIII i XIV w. rzadko zawierają słowa confiscatio czy confiscare. W wypadkach określonych jako sytuacja 2 . z reguły używane są inne, np.: alienare (NKDM 2, nr 281, s. 286, 1347 r.); intromittere (KDWP 2, nr 1275 , s. 608, 1348 r.); occupare (CDP 2/1, nr 96, s. 81, 1267 r.); recipere (Perlbach PU, s. $88, \mathrm{nr} 104,1248 \mathrm{r}$.).

${ }^{11}$ Wciąż brak monografii poświęconej prawu własności w średniowiecznej Polsce.

${ }_{12}$ Zob. hasło: Konfiskata, [w:] Uniwersalny slownik języka polskiego, red. S. Dubisz, t. 2, Warszawa 2003, gdzie słowo to odnotowane jest w trzech znaczeniach: 1) kara orzeczona przez sqad, polegajqca na utracie mienia na rzecz państwa; 2) wycofanie z obiegu druków przez odpowiednie wladze państwowe; 3) wywlaszczenie osoby prywatnej z calego lub czéści majqtku na rzecz paŕstwa (bez odszkodowania). Dla interesujących nas czasów Kazimierza Wielkiego drugie znaczenie słowa konfiskata można pominąc. Trzecie nie występuje w Slowniku jezyka polskiego, red. W. Doroszewski (przedruk elektroniczny Wyd. Nauk. PWN 1997). Warto zauważyć, iż $w$ starszych słownikach „konfiskata” to kara za cieżkie przewinienie; zob. J. Karlowicz, A. Krý́ski, W. Niedźwiedzki, Slownik jezyka polskiego, t. 2, Warszawa 1904, s. 437

${ }^{13}$ Zob. na przyklad M. Sczaniecki, Nadania ziemi na rzecz rycerzy w Polsce do końca XIII wieku, Prace Komisji Historycznej Pozn. Tow. Przyj. Nauk 1938, t. XI, z. 3, s. 29; J. Lu cińs ki, Majątki..., s. 11 i 16; J. S. M a tu s zews ki, [hasło:] Konfiskata, [w:] Wielka encyklopedia prawa, red. E. Smoktunowicz, Białystok 2000. 
„,zabór"14. Terminologia ta wszakże nie upowszechniła się. Odnieść można wrażenie, iż w nauce nie odczuwa się niekiedy potrzeby odróżniania konfiskat od zaborów i uważa się, że zbędne są tutaj dystynkcje terminologiczne ${ }^{15}$. Takie stanowisko utrudnia badaczowi problematyki zaborów, w niektórych zwłaszcza wypadkach, porozumienie $\mathrm{z}$ literaturą. Rozpatrzmy tę kwestię na kilku przykładach.

Zacznijmy od monografii państwa Kazimierza Wielkiego napisanej przez Zdzisława Kaczmarczyka, która - jak słusznie zauważył Antoni Gąsiorowski - wciąż stanowi podstawę wszelkich prac dotyczących czasów, w których rządził ów wielki monarcha ${ }^{16}$. Podejmując problem przedsięwziętej przez króla Kazimierza akcji powiększania domeny, Kaczmarczyk stwierdził między innymi, iż jego działania prowadziły do „rewindykacji” dóbr, która dotyczyła „specjalnie” majętności kościelnych, chociaż król odbierał dobra takźe rycerstwu i miastom ${ }^{17}$. Uzasadniając swój pogląd, Autor Monarchii przytoczył szereg informacji źródłowych ${ }^{18}$ i zastrzegl, że wszystkie te przyklady nie wyczerpuja

${ }^{14}$ Nazwe „zabór" wprowadził do nauki W. Semkowicz (w recenzji rozprawy K. Potkańskie go, Sprawa restytucj], KH 1901, 15, s. 104, 106, 107, passim; te nże [rec.: Potkański Karol, Jeszcze sprawa restytucj], KH 1902, 16, s. 101, 106, passim. Zabory od konfiskat wyodrębniał J. Luciński, Majq̨tki..., s. 16. Posługiwał się nią też m. in. J. Si e r a z ki, (Polska wieku XIV. Studium z czasów Kazimierza Wielkiego, Warszawa 1959, s. 204 i 215), który początkowo uważal ją za niewłaściwą dla wypadków zabierania przez króla Kazimierza posiadłości kościelnych. Zob. A. H ir s c h be rg, Stosunki osadnicze w dobrach klasztoru tynieckiego w poczqtkach jego istnienia, Lwów 1925, s. 36, przyp. 6. Używał je także A. Gą si o rowski, Donacje Kazimierza Wielkiego dla rycerstwa, Studia i Materiały do Dziejów Wielkopolski i Pomorza 1979, t. 13, z. 1 (25), s. 81-82. We wcześniejszych pracach uczony ten - jak można sądzić - nazwą ,konfiskata" obejmowal także zabory. Zob. np. te nże, Monarchia nierównoprawnych stanów, [w:] Polska dzielnicowa $i$ zjednoczona, państwo - spoleczeństwo - kultura, red. A. Gieysztor, Warszawa 1972, s. 283; K. G oźdź- R oszk owski, Zabieranie..., s. 93, przyp. 1. R. Grodecki przeciwstawial konfiskatom za zbrodnie lub opozycje politycznq zabory, lecz widział w nich przede wszystkim wypadki rewindykacji dóbr przez króla Kazimierza; R. G r ode cki, Dzialalność gospodarcza Kazimierza Wielkiego, [w:] te nże, Polska piastowska, Warszawa 1969, s. 518 i 522.

15 Przykładem używania zamiennie nazw „konfiskata” i „zabór” jest rozprawa A. Ve t u l a n i e go, Studia nad tekstami $i$ znaczeniem Statutu Eeczyckiego z r. 1180, [w:] Studia nad historiq prawa polskiego, t. XIII, z. 3, Lwów 1932, s. 41, 42, 43, 44, passim.

${ }^{16}$ A. Gą siorowski, Donacje..., s. 75 , przyp. 1.

${ }^{17}$ Z. Ka czmarczyk, Monarchia Kazimierza Wielkiego, t. I: Organizacja państwa, Poznań 1939 [cyt. dalej Z. Ka c z ma r cz y k, Monarchia I], s. 161-162.

${ }^{18}$ Ibidem, s. 162 i 163. 
oczywiście listy skonfiskowanych przez Kazimierza Wielkiego dóbr ${ }^{19}$. Wskazane przez niego przykłady dotyczyły dóbr odebranych przez króla $\mathrm{z}$ powodu popełnienia przestępstwa przez ich wlaścicieli ${ }^{20}$, ale także zabranych bez takiego związku" ${ }^{21}$, jak również dóbr, które panujący traktował jako swoją własność i uważał, że nieprawnie znalazły się w rękach prywatnych ${ }^{22}$. Kaczmarczyk nadawał więc słowu ,skonfiskowany" treść bardzo szeroką ${ }^{23}$. W cytowanym kontekście jest ono synonimem słowa „zabrany”. Dobra określone przez niego jako „skonfiskowane” były przedmiotem kary konfiskaty bądź zaboru, bądź nawet rewindykacji. Są to wszakże trzy różne sytuacje. Ich wyodrębnienie ma istotne znaczenie dla badań nad domeną monarszą. Pozwala bowiem ukazać wachlarz środków, jakimi dysponował Kazimierz Wielki, odbudowując swoją domenę.

19 Ibidem, s. 164. O posiadlościach skonfiskowanych przez Kazimierza Wielkiego i wcielonych do dóbr królewskich napomknąl później, w związku z „akcją restytucyjną” za Ludwika Węgierskiego, Z. K a c zm a r czyk, Polityka gospodarcza i centralizacja Monarchii do 1370 r., [w:] Historia Polski PAN, t. I: do roku 1764, cz. 1: do pol. $X V$ w., red. H. Łowmiański, PWN 1957, s. 558.

${ }^{20}$ Uczony wymienił trzy dokumenty, które jego zdaniem dowodziły, że podstawą włączenia dóbr do domeny królewskiej byly także wyroki sądowe przewidujqce kare konfiskaty: KDMP 3, s. 140, nr 739 (1360); ibidem, s. 160-161, nr 758 (1363); KDWP 3, s. 345-346, nr 1627 (1370). Kontekst pierwszego dokumentu pozwala interpretować wyrażenie: ad nos iure deuoluta fuisset et nostro dominio confiscata niekoniecznie tylko w tym kierunku, iż król skonfiskował dobra S., na podstawie wyroku sadowego, lecz dlatego, iż przypadly mu prawnie (ex causa legitima). O owej causa - przestępstwo zdrady dotychczasowych właścicieli - dokument obszernie informuje. Drugi dokument nie wskazuje, iż konfiskata została orzeczona wyrokiem sądowym. Przedmiotem rozpoznania sądu była skarga windykacyjna trzech braci (heredum de P.), których nieruchomość znajdująca się w zastawie u przestępcy została wraz z całym jego majątkiem zabrana przez króla. Jedynie trzeci dokument potwierdza myśl Kaczmarczyka, z tym jednak zastrzeżeniem, iż król skonfiskowanej posiadłości nie wcielił do swych majątków, lecz zamienił na dwie inne $z$ arcybiskupem gnieźnieńskim. Teza Kaczmarczyka wydaje się więc słabo udokumentowana. Tymczasem wpłynęła na treść opracowań o charakterze syntetycznym i podręcznikowym, które informują: Do zwiększenia dóbr królewskich [za panowania Kazimierza Wielkiego - uzup. K. G. R.] przyczynily się też konfiskaty dóbr na podstawie wyroków sqdowych. Zob. J. B a rdach, Historia państwa $i$ prawa Polski, t. I: do polowy $X V$ wieku, Warszawa 1964, s. 468. Akademicki podręcznik (J. B a r d a ch, B. Leśn od or ski, M. Pietrzak, Historia ustroju i prawa polskiego, Warszawa 1993, s. 116) dodaje, iż owe konfiskaty były częste.

${ }^{21}$ W wypadku utraty Jasła i Pukarzewa przez cystersów z Koprzywnicy, już K. P o tkański (Sprawa..., s. 7-8) wykazał, że nie miała ona charakteru kary.

${ }^{22}$ Np. wsie Jeżyce i Winiary, które skonfiskowal król miastu Poznaniowi; Z. K a c z m a r c z y k, Monarchia I, s. 163.

${ }^{23}$ Również w późniejszych swych pracach, poświęconych kazimierzowskiej monarchii Kaczmarczyk nadawał „konfiskacie" szerokie znaczenie. Zob. Z. K a c z ma r c y y, Monarchia Kazimierza Wielkiego. Organizacja Kościola, sztuka i nauka, Poznań 1946, [dalej: Z. Ka czma rcz y k, Monarchia II], s. 206, 210, 211; te nż e, Kazimierz Wielki (1333-1370), Warszawa 1948, s. 270, 302-303; t e nże, Polska czasów Kazimierza Wielkiego, Kraków 1964, s. 59, 85, 86, $87,105,149$. 
Odnosi się wrażenie, że Kaczmarczyk dostrzegał jednak, iż nazwa „konfiskata" jest wieloznaczna. Podsumowując bowiem swoją wypowiedź na temat stworzonego przez Kazimierza Wielkiego systemu odbudowy domeny, pisał:

$Z$ jednej strony restytuowal król tytuly utracone $w$ czasach dawniejszej zawieruchy politycznej, $z$ drugiej wystepowal przeciwko tym, którzy nie pelnili powinności wojskowej $z$ dóbr, wzglednie okazywali panujacemu nieposluszeństwo ${ }^{24}$.

A zatem na ów system składały się restytucje, czyli odbieranie tych posiadłości, które niegdyś stanowiły własność monarszą, oraz zabieranie cudzych dóbr za karę, a więc konfiskaty w przyjętym przez nas znaczeniu. W Monarchii Kaczmarczyk pominął milczeniem ważną kwestię, czy „restytuowane" przez króla dobra znalazły się w rękach prywatnych legalną drogą, czy też zostały zagrabione, ku czemu istniały sprzyjające warunki właśnie w okresie rozbicia dzielnicowego. Wiadomo, iż takie sytuacje miały wówczas miejsce ${ }^{25}$. Ale wiadomo też, że panujący swoją ziemię również sprzedawali, darowywali itp. ${ }^{26}$ Do tych działan króla, które dotyczyły dóbr zagrabionych, odpowiadałoby raczej używane przez Kaczmarczyka określenie „rewindykacja"27. Działania te prowadzily bowiem do odzyskania posiadania obiektów stanowiących własność królewską. Natomiast odbieranie posiadłości wcześniej sprzedanych czy darowanych dotyczyło dóbr cudzych, było pozbawieniem prawa własności ich dotychczasowych posiadaczy. Dla takich sytuacji proponujemy nazwę „zabór". Obejmowanie rewindykacji i zaborów jedną wspólną nazwą „restytucje” wydaje się niewłaściwym ${ }^{28}$. Zauważmy, iż od czasów Karola Potkańskiego opatruje się nią wypadki, w których panujący oddaje osobom prywatnym zabrane posiadłości ${ }^{29}$. Wobec tego jest ona wieloznaczną.

${ }^{24}$ Monarchia I, s. 164.

${ }^{25}$ Zob. na przykład M. Sc zaniecki, Nadania..., s. 146; J. Lu ciński, Majqtki..., s. 88-90.

${ }^{26}$ J. Luciński, Majqtki..., s. 51-88.

${ }^{27}$ Zastosował go J. B a rd a ch, Historia państwa..., s. 428. Zob. też podręcznik J. B a rda ch, B. Leśnodorski, M. Pietrzak, Historia ustroju..., s. 101.

${ }^{28}$ Używa jej Z. Kaczmarczyk także w dalszych pracach, zob. tenże, Monarchia II, s. 202; t e n ż e, Kazimierz..., s. 302; t e n że, Polska czasów..., s. 149. W takim samym znaczeniu też J. Dą b r ow ski, Kazimierz Wielki - twórca Korony Królestwa Polskiego, Wrocław-Warszawa-Kraków 1964, s. 69. A także F. K iryk i J. R y ś - współautorzy Wielkiej Historii Polski, t. II: 1320-1506, Kraków 1997, s. 63 i 82.

${ }^{29} \mathrm{~W}$ tym znaczeniu używal jej wspomniany w poprzednim przypisie J. Dąbrowski we wcześniejszym dziele; te ṅ̇e, Dzieje Polski średniowiecznej, t. II: od roku 1333 do 1506, oprac. J. Wyrozumski, Kraków 1995, s. 178-179. Zob. też J. M a tuszewski, Problem konfiskaty..., s. 7. 
Należy jednak dodać, iż w późniejszych swych pracach Kaczmarczyk uściślił znaczenie słowa „rewindykacja”. Tak określone działania króla Kazimierza dotyczyły - pisał - dawnych dóbr królewskich, które w nieuczci$w y$ sposób $w$ dobie zamieszek wojennych dostaly sie $w$ rece prywatne $e^{30}$. Wszakże rewindykacyjne posunięcia króla skierowane były względem instytucji kościelnych oraz miast, i tam nazywa je „konfiskatami”. W wypadku Kościola monarcha czynił je pod różnymi pozorami ${ }^{31}$. Wypowiedź ta rodzi kolejne pytania, na przykład: czy ,własna ważna potrzeba" króla, to tylko pozór, a może rzeczywista przyczyna, dla której zabierał dobra, dokonując zaborów posiadłości kościelnych, i czy tak potężny wladca, jakim był Kazimierz Wielki, musiał szukać pozorów dla odebrania swojej własności.

Również późniejsi badacze nadawali słowu ,konfiskata” szeroką treść. Kazimierz Kolańczyk pisal: konfiskowal wreszcie król otwarcie, choć pod różnymi pozorami, ale $w$ istocie dla celów strategicznych niektóre dobra klasztorne $e^{32}$. Nazwa „konfiskata” oznaczała dla niego zabranie przez panującego dóbr z przyczyn innych niż ukaranie ich wsłaściciela, jednakże - odmiennie niż u Kaczmarczyka - nie obejmowala wypadków rewindykacji dóbr monarszych. Wzmiankując bowiem o rewizji tytułów własności, która za Kazimierza Wielkiego nie ominęła Kościoła, Kolańczyk zuważył: akcja ta musiala niejednokrotnie oscylować na pograniczu pomiędzy istotnym przywróceniem posiadania a konfiskatq ${ }^{33}$. Jak widać, nazwę „konfiskata” odnosil do sytuacji, które nazywamy zaborami. W takim jej zastosowaniu Kolańczyk nie był wszakże konsekwentnym. Używał bowiem również nazwy ,zabór" - być może pod wpływem Władysława Abrahama - gdy wspominal o wypadkach zabierania przez książąt dóbr kościelnych w XIII $w^{34}$

Poruszając kwestię utraty własności w okresie monarchii stanowej, Juliusz Bardach stwierdzil:

Na plan pierwszy $w$ XIV $w$. wysunęly sie tu konfiskaty, które nastepowaly nieraz bez wyroku sqdowego na podstawie arbitralnej decyzji monarchy. Szeroko byly stosowane konfiskaty za rzqdów Kazimierza Wielkiego wobec panów świeckich $i$ instytucji kościelnych, którzy w okresie rozdrobnienia zawlaszczyli ziemie monarsze. Ponieważ uderzalo to szczególnie dotkliwie nie tylko $w$ winnych, ale $i$ w ich rodziny oraz dawalo okazje do licznych naduzyc, rycerstwo przeciwstawialo sie praktyce arbitralnych konfiskat... ${ }^{35}$

${ }^{30}$ Z. Kaczmarczyk, Kazimierz..., s. 270; to samo tenże, Polska czasów..., s. 85.

${ }^{31}$ Zob. przyp. poprzedni.

${ }^{32} \mathrm{~K}$. Kolańczyk, Studia nad reliktami wspólnej wlasności ziemi w najdawniejszej Polsce. Rozporzqdzanie wlasnościq ziemskq do końca XIV w., Poznań 1950, s. 362.

${ }^{33}$ Loc. cit.

${ }^{34}$ Ibidem, s. 359-360.

${ }^{35} \mathrm{~J}$. B a rdach, Historia państwa..., s. 502. 
Z kontekstu można wnosić, iż chodzi o karę konfiskaty, która z woli Kazimierza Wielkiego spotkała tych, którzy niegdyś zagarnęli majątki monarsze. Zwłaszcza iż dalej wspomniano, że rycerstwo uzyskało $w$ przywileju czerwińskim zakaz konfiskaty mienia bez wyroku sqdu. Rzecz jednak w tym, iż nic nie wiadomo, aby tego rodzaju czyny były traktowane jako przestępstwo, $i$ to karane konfiskatą mienia nieruchomego. Sam Bardach, pisząc o przestępstwach i karach, o tym nie wspomina. Natomiast, charakteryzując dochody skarbowe w XIV w., uczony ten zauważyl, że rozmiary dóbr królewskich i płynące $\mathrm{z}$ nich dochody wzrosly za rzqdów Kazimierza Wielkiego, kiedy przeprowadzono na szeroka skale akcje rewindykacji dóbr królewskich ${ }^{36}$. Tutaj następuje odesłanie do cytowanego wyżej tekstu. Wnosić należy przeto, iż wspominając w nim o konfiskatach, które spotkały rycerstwo i instytucje kościelne, autor miał na myśli jednak nie karę przepadku mienia, lecz rewindykacje majątków monarszych, które zostały przez nie przywłaszczone. Powstaje w takim razie pytanie, czy zasadnym bylo wymienianie owych „konfiskat” jako przyczyny utraty własności. Król Kazimierz bowiem, dokonując rewindykacji, odbieral dobra własne. Rycerstwo i instytucje kościelne prawa własności do nich nie posiadaly. A zatem i utracić tego prawa nie mogły. Dokonywane przez nich zawłaszczenia ziemi monarszej nie miały podstawy prawnej. Bardach nazywa te działania zaborami i zauważa, że je sankcjonowano nieraz ex post dokumentami nadawczymi ${ }^{37}$. $\mathrm{Z}$ kolei zawlaszczenia zalegalizowane przez władce rewindykacji nie podlegały. Sądzić można, że wątpliwości interpretacyjne i nieporozumienia, jakie rodzi wypowiedź Bardacha o konfiskacie majątku stanowiącej przyczynę utraty wlasności, wynikają właśnie $\mathrm{z}$ wieloznaczności nazwy „konfiskata" w literaturze naukowej.

Podsumowując dotychczasowe badania nad reorganizacją domeny monarszej w czasach Władysława Lokietka i jego następcy, Janusz Kurtyka wspomnial, iż owa reorganizacja była realizowana między innymi przez konfiskaty dóbr. Słusznie też określił podejmowane przez króla działania jako akcje administracyjne ${ }^{38}$. Król zabierał bowiem dobra niejednokrotnie bez wyroku sądowego. Konfiskaty dotyczyły - zdaniem Kurtyki - dóbr zajetych przez szlachte na szkode Kościola $i$ monarchii oraz posiadanych przez osoby uznane za wrogów króla ${ }^{39}$. Wspomniany badacz posługuje się nazwą konfiskata w specyficznym znaczeniu. Określone nią działania monarchy wykazują bowiem dwie cechy łącznie. Mają charakter rewindykacji $i$ represjit ${ }^{40}$.

\footnotetext{
36 Ibidem, s. 468.

${ }^{37}$ Ibidem, s. 298.

${ }^{38}$ J. K u r ty k a, Odrodzone królestwo. Monarchia Wladyslawa Lokietka i Kazimierza Wielkiego $w$ siwietle nowszych badań, Kraków 2001, s. 143.

${ }^{39}$ Loc. cit. Można dopatrywać się tu wpływu, w pewnym stopniu, rozpatrywanych wyżej sformułowań J. Baradacha, którego dzieło autor zamieścił w spisie literatury.

${ }^{40}$ Loc. cit.
} 
Rewindykację rozumiemy jako odebranie przez króla wlasnych dóbr z rąk osób świeckich czy też instytucji kościelnych posiadających je bez tytułu prawnego. Tymczasem konfiskata - jak zauważyliśmy na początku niniejszego szkicu - jest kasatą prawa do majątku, zwłaszcza prawa własności. Przeto konfiskata ex definitione nie może być zarazem rewindykacją. Tak więc nie miały charakteru rewindykacji konfiskaty, które dotykały rzeczywistych czy też domniemanych wrogów królewskich. Również w zabieraniu przez króla szlachcie dóbr zagarniętych przez nią Kościolowi nie widać cech rewindykacji, bowiem $\mathrm{w}$ takiej sytuacji monarcha zabierałby cudzą ziemię, bo kościelną, a nie odbieral swoją. Rewindykacją była natomiast trzecia wskazana przez Kurtykę sytuacja, kiedy król odbieral szlachcie swoje własne dobra przez nią przywłaszczone. Ze względu jednak na to, iż chodziło tutaj o dobra królewskie, nie jest dla niej odpowiednią nazwa konfiskata ${ }^{41}$.

Zwróćmy uwage na kwestię represyjności cechującej - zdaniem Kurtyki - konfiskaty. Zabieranie dóbr we wszystkich sytuacjach określonych tą nazwą wyrządzało ich posiadaczom dolegliwość. Można więc się zgodzić, iż z tego względu miały one charakter represji, wszakże tylko w bardzo ogólnym znaczeniu tego słowa ${ }^{42}$. $\mathrm{Z}$ punktu widzenia bowiem prawa karnego, charakter taki miały tylko wypadki zabierania dóbr wrogom króla. Zauważyć na koniec trzeba, iż Kurtyka - odmiennie od innych autorów - słusznie nie zastosowal nazwy konfiskata względem zaborów. Wspomniał o nich, osobno wzmiankując o arbitralnym przejmowaniu przez króla niektórych dóbr rycerskich $i$ kościelnych $w$ drodze zajecia lub przymusowej zamiany ${ }^{43}$.

Rozpatrywana wyżej wypowiedź Janusza Kurtyki wpłynęła - jak można sądzić - na stanowisko zajmowane przez Stanisława Szczura. Autor Historii Polski (Średniowiecze) wymienił konfiskaty jako jeden ze środków, który służył władcy do powiększania domeny. Podobnie, jak i u Kurtyki, dotyczyły one zajętych przez rycerstwo dóbr kościelnych oraz majątków należących do wrogów króla. Jednak nie wspomnial, by przedmiotem owych konfiskat były też zagarnięte przez rycerstwo dobra monarsze ${ }^{44}$. Osobnym, a ważnym sposobem powiększania domeny byla - zdaniem Stanisława Szczura - kontrola tytułów własności, której rezultatem mogła być utrata dóbr na rzecz

${ }^{41} \mathrm{~W}$ przyjętym sposobie pojmowania konfiskat brak konsekwencji. Oto nie zaliczono do nich, skądinąd słusznie, wypadków zabierania rycerstwu posiadłości, których nadanie lub posiadanie nie bylo potwierdzone dokumentem (loc. cit.). Brak dokumentu rodził domniemanie, iż takie majątki stanowiły własność monarszą. Podobnie R. Grodecki, Dzialalność..., s. 512.

${ }^{42} \mathrm{~W}$ takim znaczeniu Kolańczyk zaliczał wypadki zaborów dóbr kościelnych przez panujących do środków represyjnych, przeciwstawiając im środki prewencyjne, które łącznie miały zapobiegać nadmiernemu rozrostowi własności kościelnej w średniowiecznej Polsce; K. Kolańczyk, Studia nad reliktami..., s. $359 \mathrm{i} \mathrm{n}$.

43 J. K urtyk a, Odrodzone królestwo..., s 143.

${ }^{44}$ S. Szczu r, Historia Polski. Średniowiecze, Kraków 2002, s. 429. 
monarchy ${ }^{45}$. Takie sytuacje zaliczylibyśmy, zależnie od okoliczności, do rewindykacji bądź do zaborów. Jako ostatni środek powiększania domeny wymienił on przejmowanie przez króla siłą dóbr prywatnych bez pytania wlaścicieli o zgode $e^{46}$. Chodzi tu zapewne o zabory, wszakże taki termin nie został w rozpatrywanym tekście użyty. Można by sądzić, iż Autor używał nazwy „konfiskata” w znaczeniu kary, która dotykała między innymi osoby uznane za wrogów królewskich. Taki jednak wniosek podważa sformulowane dalej stwierdzenie, dotyczące całości opisywanych wcześniej działań Kazimierza Wielkiego:

Przeprowadzona w czasach Ludwika Wielkiego akcja restytucyjna pokazuje, $\dot{z} e$ konfiskaty dokonywane przez króla mialy znaczny zasieg $i$ objelly zarówno Malopolske, jak $i$ Wielkopolske $e^{47}$.

Czyżby ostatecznie wszystkie wymienione wyżej działania króla, mające na celu powiększenie domeny, sprowadzal Autor do szeroko rozumianych „konfiskat”? Wcześniej, opisując czasy regencji Elżbiety Lokietkówny w Polsce, zauważa, iż rycerstwo małopolskie podnioslo sprawe konfiskat dóbr dokonywanych przez Kazimierza Wielkiego. I wyjaśnia: konfiskowano je tym, którzy nie byli w stanie wykazać sie tytulami prawnymi do posiadanej ziemi. Królewskie represje dotknęly zarówno dobra rycerskie, jak i kościelne ${ }^{48}$. Odnosi się wrażenie sprzeczności. Zabranie przez króla ziemi, co do której istniało uzasadnione domniemanie, iż była własnością monarszą, jest nazwane konfiskatq. Tymczasem w dalszej części dzieła ta sama sytuacja potraktowana została - jak widzieliśmy - jako konsekwencja odrębnego od „konfiskat”, ważnego elementu w odbudowie monarszej domeny: kontroli tytulów wlasności.

Wątpliwości budzi również traktowanie jako represji wypadków odbierania dóbr monarszych dokonywanych przez króla Kazimierza w ramach kontroli tytułów własności. Kontrola ta miała wszak charakter powszechny - dotykała zarówno tych posiadaczy ziemskich, którzy cieszyli się łaską królewską, jak i tych, którym jej odmówiono. Przykładem mogą być miasta Kalisz i Poznań. Tak pierwsze, ze względu na dochowanie wierności Lokietkowi obsypywane dobrodziejstwami, jak i drugie, które opowiedziało się za synami Henryka Glogowskiego i z tego powodu nie otrzymywało przywilejów od ostatnich Piastów na tronie polskim, utracily w ramach wspomnianej kontroli niektóre posiadane ssie $^{49}$.

${ }^{45}$ Loc. cit.

${ }^{46}$ Loc. cit.

${ }^{47}$ Loc. cit.

${ }^{48}$ Ibidem, s. 402.

${ }^{49}$ Tezę o nierepresyjnym charakterze odebrania przez Kazimierza Wielkiego Poznaniowi wsi Jeżyce i Winiary wysunęła $\mathrm{H}$. Zi ó $1 \mathrm{k}$ o w s k a, Poznań w okresie przezwyciężania rozdrobnienia 
Ostatnim z badaczy dostarczającym nam przykładu zastosowania nazwy „konfiskata” jest Sławomir Gawlas, który słusznie zauważyl, iż w czasach Kazimierza Wielkiego konfiskaty byly od dawna stosowana, normalna kara za przestepstwa kryminalne $e^{50}$. Tak rozumianych konfiskat nie utożsamiał $\mathrm{z}$ rewindykacjami monarszych posiadlości. Wszakże pod nazwą rewindykacje kryją się u niego rozmaite działania króla, między innymi takie, które określił jako wywlaszczenia ${ }^{51}$. Jeśli te ostatnie będziemy rozumieć najogólniej, a więc jako wypadki pozbawienia własności, to nazwa „rewindykacje” wydaje się dla nich niewłaściwą ${ }^{52}$.

Wyniki analizy zaprezentowanych przykładowo wypowiedzi literatury, posługujących się nazwą „konfiskata" zostały ujęte w postaci tabeli:

\begin{tabular}{|l|l|l|l|}
\hline \multicolumn{1}{|c|}{ Autor } & \multicolumn{3}{|c|}{ Treść nazwy ,konfiskata” } \\
\hline Z. Kaczmarczyk & kara & zabór & rewindykacja \\
K. Kolańczyk & --- & zabór & -- \\
J. Bardach & kara & -- & rewindykacja \\
J. Kurtyka & kara & -- & rewindykacja \\
S. Szczur & kara & zabór & rewindykacja \\
S. Gawlas & kara & -- & -- \\
\hline
\end{tabular}

feudalnego $i$ wyksztalcenia sie feudalnej monarchii stanowej. 1253-1450, [w:] Dziesięć wieków Poznania, red. K. Malinowski, t. 1: Dzieje spoleczno-gospodarcze, Poznań-Warszawa 1956, s. 51-52. Podzielał ją A. G ąs s o r o ws k i, Miasto późnośredniowieczne, [w:] Dzieje Poznania, red. J. Topolski, t. 1, Warszawa-Poznań 1988, s. 213, przyp. 12. Odmienne stanowisko zajmował Z. K a c z m a r z y k, Stanowisko Kazimierza Wielkiego wobec Poznania, Kronika m. Poznania 1938, R. 16, nr 3, s. 257-262. Pisząc o licznych przejawach łaski królewskiej dla Kalisza, Kaczmarczyk nie ustrzegł się jednostronności, skoro pominął milczeniem sprawę utraconej przez miasto wsi Dobrzec, a restytucję zabranego przez króla Tyńca przedstawił jako jego darowiznę; t en że, Rzady Kazimierza Wielkiego w Kaliszu, Przegląd Wielkopolski 1939, R. 1, nr 4, s. 117. W kwestii Tyńca i Dobrca zob. K. Potkański, Sprawa.., s. 24.

so S. Gawlas, Monarchia Kazimierza Wielkiego a spoleczeństwo, [w:] Genealogia - Wladza $i$ spoleczeństwo w Polsce średniowiecznej, red. A. Radzimiński, J. Wroniszewski, Toruń 1999, s. 222.

${ }^{51}$ Loc cit.

${ }_{52}$ Co rozumie autor przez wywlaszczenie nie jest jasnym. Wymienia bowiem, oprócz wywłaszczen, nieekwiwalentne zamiany i przejmowanie przez króla cudzych dóbr pod pozorem poprawienia ich stanu gospodarczego, które prowadziły lub prowadzić mogły również do utraty prawa własności przez ich dotychczasowych posiadaczy; loc. cit. 
W literaturze - jak wskazują przykłady - nazwa „konfiskata” jest wieloznaczna. Oznacza przepadek dóbr na rzecz monarchy, następujący wskutek popelnienia przestępstwa przez ich właściciela (kara), oznacza także pozbawienie właściciela jego dóbr nie mające charakteru kary (zabór) oraz odebranie dóbr dzierżonych bez podstawy prawnej, stanowiących własność monarszą (rewindykacja). Dwa pierwsze znaczenia „konfiskaty" odnotowały współczesne słowniki polskiego języka potocznego. Nie rejestrują one natomiast tego słowa w znaczeniu „rewindykacji”. Obserwujemy zatem niepokojące zjawisko $w$ nauce. Zamiast uściślania znaczenia używanych słów następuje pogłębianie ich wieloznaczności. Banalnym jest stwierdzenie, iż pożądany byłby proces zmierzający $w$ odwrotnym kierunku.

Posługiwanie się słowem wieloznacznym niepotrzebnie naraża czytelnika na trud nieustannej kontroli, w jakim sensie owo słowo zostało użyte ${ }^{53}$. Co gorsza, niekoniecznie uwieńczony powodzeniem. Zawsze bowiem istnieje możliwość, iż intencja autora tekstu zostanie blędnie odczytana i powstanie brzemienne $w$ skutki nieporozumienie.

Rezygnowanie z precyzji, jeśli idzie o znaczenie nazwy „konfiskata”, ujemnie wpływa - wbrew intencjom badaczy - na rezultaty studiów nad reorganizacją domeny monarszej przez Kazimierza Wielkiego. Czyni bowiem mniej przejrzyste ujęcia syntetyczne. Dość dhuga niekiedy lista środków, z których król korzystał przy jej powiększaniu, da się być może sprowadzić do trzech głównych pozycji: rewindykacje, zabory oraz konfiskaty. Zamiany wymuszone przez króla w zasadzie nie zwiększały jego posiadłości. Jeśli zaś były nieekwiwalentne, to $w$ istocie dochodziło wówczas do zaborów, których monarcha dokonywał, zresztą na różne sposoby. Natomiast przejmowanie przez króla dóbr klasztornych na czas swego życia ad meliorationem praktykowane było - w świetle źródeł malopolskich - rzadko ${ }^{54}$.

Oprócz nazwy „konfiskata” używane są także inne wieloznaczne nazwy. Ubocznie zwróciliśmy uwage na „restytucje” i „rewindykacje”. Pierwsza oznaczać może bądź zwrot cudzej majętności przez panującego, bądź też odebranie przezeń dóbr własnych, a także stanowiących czyjąś własność. A więc jedna nazwa funkcjonuje dla określenia dwu przeciwstawnych procesów: umniejszania i powiększania domeny panującego. Synonimem „restytucji”, w jej drugim znaczeniu, stała się ,rewindykacja”.

Używanie wspólnej nazwy „rewindykacja” czy też „restytucja” dla wypadków zabierania przez panującego dóbr cudzych i odbierania własnych,

${ }^{33}$ Zob. na przykład J. D ow ia t, Polska - państwem średniowiecznej Europy, Warszawa 1968, s. 355 i 359.

${ }^{54}$ J. Lu ciński, Majqtki..., s. 49. 
zachodzących $\mathrm{w}$ związku $\mathrm{z}$ odbudową domeny, jest prawdopodobnie konsekwencją poglądu, że powstanie własności feudalnej w Polsce wiąże się $z$ nadaniami panującego ${ }^{55}$. Grozi wytworzeniem mylnego wrażenia, iż odbudowa domeny przez Kazimierza sprowadzała się ostatecznie do wielkiej rewindykacji dóbr królewskich, gdy tymczasem na ten proces złożyly się również zabory, a także konfiskaty majętności stanowiących własność innych niż monarcha posiadaczy ziemskich.

${ }^{55}$ H. Low mi á ski, Poczatki Polski. Polityczne i spoleczne procesy ksztaltowania się narodu do poczqtku wieku XIV, t. VI/1, Warszawa 1985, s. 394-398; w dziele tym zaprezentowano wcześniejszą literaturę, ibidem, s. 234 i n.; S. S zczur, Historia Polski..., s. 162-163; K. Ole jn ik, Historia Polski do roku 1386, Poznań 1996, s. 82. Zob. też S. Pł a za, Historia prawa w Polsce na tle porównawczym, cz. I: X-XVIII w., Kraków 1997, s. 267. J. B a r a ch przypisuje, obok nadań, znaczącą rolę w powstaniu feudalnej własności świeckiej zawłaszczeniom, te nż̀, Historia państwa..., s. 101. 